\title{
Mission Moho Workshop: Drilling Through the Oceanic Crust to the Mantle
}

\author{
by Benoit Ildefonse, David M. Christie, and the \\ Mission Moho Workshop Steering Committee
}

\section{Introduction}

The Mohorovičić discontinuity (Moho) is a seismically imaged, first order acoustic interface assumed to represent the transition between the Earth's crust and the underlying mantle in both continental and oceanic settings. To date, this elusive frontier has been a symbolic goal for many geologists, but beyond the reach of available drilling technology. With the recent commissioning of the Chikyu, a new riser-drilling vessel of the Integrated Ocean Drilling Program (IODP), the technically challenging goal of drilling to and through the Moho within the ocean basins becomes feasible.

The formation and evolution of the oceanic lithosphere are the dominant processes in the chemical differentiation and physical evolution of our planet. This evolution encompasses the transfer and transformation of material and energy from Earth's mantle to the crust, and from the crust to the ocean and atmosphere. Independent of sunlight, the evolving ocean crust supports life in unique subsurface and seafloor habitats that may resemble the earliest of Earth's ecosystems. From its formation until its return by subduction to the mantle, the oceanic lithosphere interacts with seawater, sequesters surface materials (including water), and recycles them back into the mantle.

In April 1961, the first successful drilling and coring of oceanic basement recovered a few meters of basalt in
3800 meters water depth offshore Guadalupe Island, Mexico. This remarkable breakthrough was the first stage of Project Mohole, a much more ambitious project to drill through the ocean crust to the Moho (e.g., Bascom, 1961; Shor, 1985). Over the last 45 years, this fundamental goal has not been achieved, but it has been consistently reiterated in the successive plans of the Deep Sea Drilling Project (DSDP), the Ocean Drilling Program (ODP), and the IODP.

Since the end of the 1960s, tens of holes have been drilled and cored into oceanic basement (Fig. 1). These have led to major improvements in our understanding of oceanic crustal architecture and of mid-ocean ridge processes (Dick et al., 2006; Ildefonse et al., 2007). To date, however, only four deep basement holes have penetrated more than 1000 meters into oceanic basement (Fig. 2). IODP's most recent successes in this arena are two deep holes at complementary sites. Hole U1309D, in slow-spread Atlantic Ocean crust, reached $1415 \mathrm{~m}$ below sea floor and recovered a complex series of gabbroic rocks (Blackman et al., 2006; Ildefonse et al., 2006); and Hole 1256D, in the superfast-spread crust of the eastern Pacific Ocean, reached $1507 \mathrm{~m}$ below seafloor and, for the first time, passed through a complete Layer 2 (pillow basalt and sheeted dike) sequence into the transition between sheeted dikes and underlying gabbros (Wilson et al., 2006; Alt et al., in press). These two holes have provided considerable experience in deep ocean crustal drilling, complementing that from the two earlier deep and successful ODP Holes

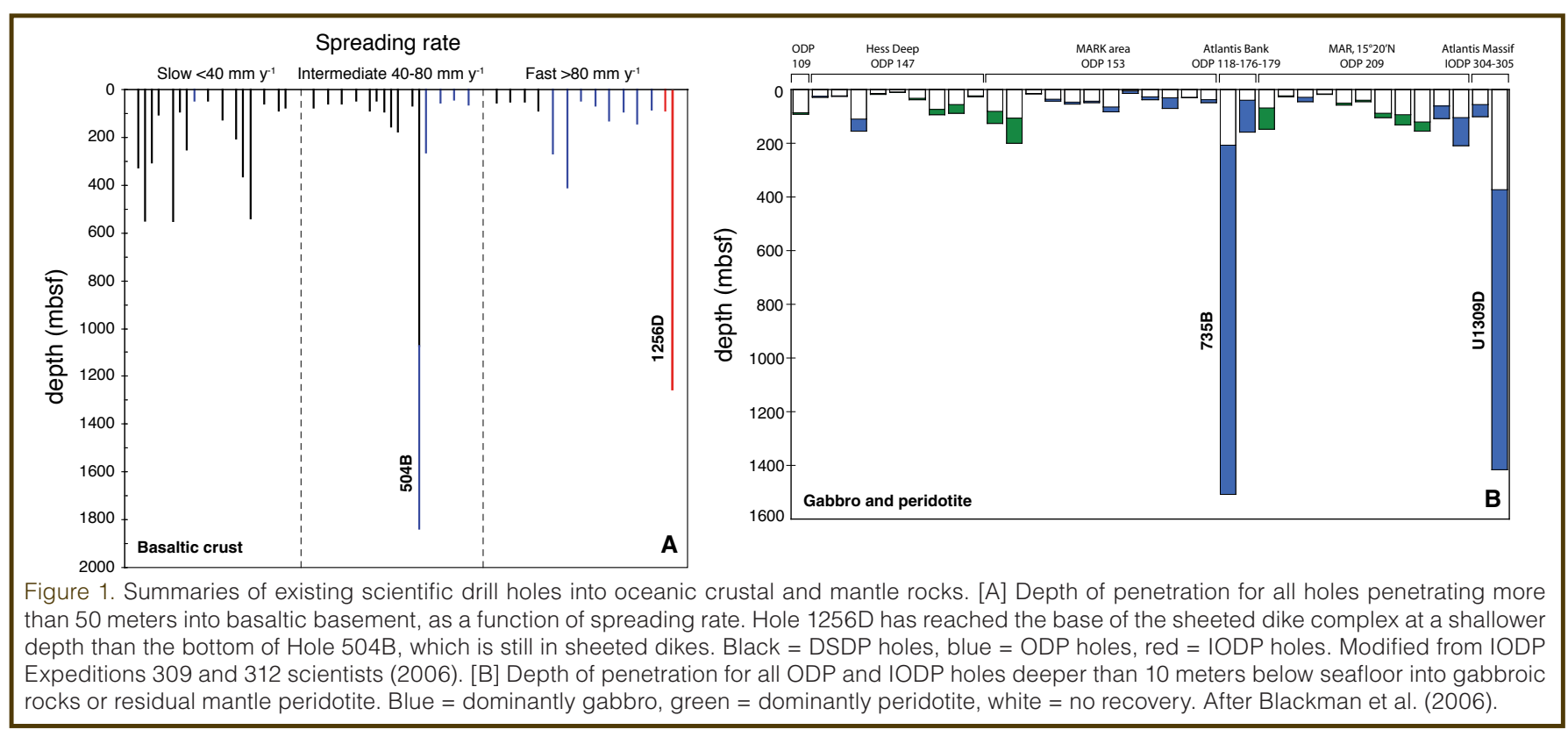




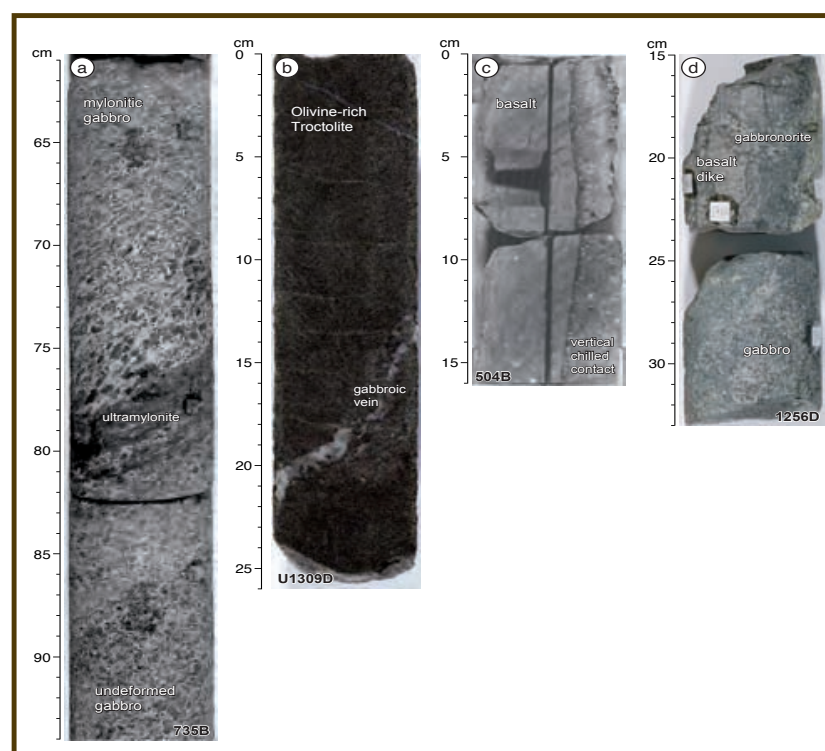

Figure 2. Core pieces from the four deepest holes in the ocean crust. [A] The gabbroic section recovered in Hole 735B (Atlantis Bank, Southwest Indian Ridge; Dick, et al., 1999) is unique in that as much as $23 \%$ of the core is plastically deformed. The picture shows the base of a 20 -meters-thick shear zone at $964 \mathrm{~m}$ below seafloor

[B] Olivine-rich troctolite from Hole U1309D (Atlantis massif, MidAtlantic Ridge; Blackman, et al., 2006) at $1194 \mathrm{~m}$ below seafloor. These troctolites contain as much as $90 \%$ olivine, and are locally extremely fresh (<1\% serpentinization). [C] Hole 504B (Guatemala basin, Eastern Pacific) sampled for the first time the in situ sheeted dike complex, as illustrated by this sample of a vertical chilled contact between two basaltic dikes recovered at $\sim 1352.9 \mathrm{~m}$ below seafloor (Becker, Sakai et al., 1988). [D] The transition zone from sheeted dikes to gabbro was reached for the first time in Hole 1256D (Expedition 309 and 312 Scientists, 2006). The picture shows the contact between basaltic dike and gabbro units at $\sim 1488$ meters below seafloor. The basalt is invaded by gabbronorite from the gabbro unit.

504B and 735B in the eastern Pacific Ocean (Guatemala Basin) and Indian Ocean, respectively.

The Mission Moho workshop, was convened in Portland, Oregon (7-9 September 2006) to provide an opportunity for the scientific community to define the scientific goals for deep crustal drilling, to propose elements of a global strategy, and to develop community priorities in pursuit of IODP's 21st Century Mohole Initiative-“to advance significantly our understanding of the processes governing the formation and evolution of oceanic crust" (IODP Initial Science Plan, International Working Group, 2001). The workshop focused on the development of a scientific and operational framework that can guide an IODP Mission Moho for a decade or longer. An important part of this framework is to identify the scientific and engineering objectives that can be addressed immediately with available technology, while leading us toward the ultimate "Mohole"-a complete in situ section through the ocean crust-at a later stage.

\section{The Journey to the Moho: Formation and Architecture of the Ocean Crust}

Since the early 1970s, the standard model of a uniformly layered ocean crust has evolved significantly. Ocean drilling and other marine geological and geophysical data have demonstrated a spatially highly variable crustal architecture to be present. Ocean crust produced at fast spreading ridges is believed to be close to the layered "Penrose" stratigraphy developed from ophiolites (Penrose conference participants, 1972; Fig. 3). That is, it appears to be uniformly layered and fairly homogeneous, reflecting a relatively uniform mode of accretion (e.g., Macdonald et al., 1984; Detrick et al., 1993; Hooft et al., 1996).

In contrast, crust created at slow and ultra-slow spreading ridges is spatially heterogeneous over distances as small as a few hundred meters, both along and across isochrons. Along parts of slow spreading ridges (for example, the centers of ridge segments in the northern Atlantic), magmatic processes dominate, and recent seismic imaging has for the first time revealed a magma chamber beneath the Mid-Atlantic Ridge at $37^{\circ} 18^{\prime} \mathrm{N}$ (Singh et al., 2006). This result tends to support the hypothesis that such magmatically robust, slow-spread segments are fundamentally similar to those of fast spreading ridges. However, this similarity is limited in space, and the architecture of the crust accreted at slow-spreading ridges typically changes along-axis toward segment ends, where it is more heterogeneous and even discontinuous, with a mixture of serpentinized peridotite and gabbroic intrusions locally capped by lavas with or without intervening sheeted dikes (Fig. 4; Cannat, 1993). This lateral and vertical variability has been well-documented through seafloor geological studies and geophysical surveys, in addition to scientific ocean drilling expeditions (e.g., Karson and Elthon, 1987; Dick, 1989; Cannat et al., 1995, 2006; Canales et al., 2000; Kelemen, Kikawa, Miller, et al., 2004).

The direct route to the Moho: There was a clear workshop consensus that the first priority for a Mission Moho should be a deep, full crustal penetration hole through the Moho and into the uppermost mantle at a single site and that the first full-penetration hole should be in fast-spread ocean crust. Although only about $20 \%$ of modern ridges are spreading at fast $\left(>80 \mathrm{~mm} \mathrm{yr}^{-1}\right)$ rates, fully half of the present day ocean crust, equivalent to $\sim 30 \%$ of the Earth's surface, was produced at fast spreading centers. In other words, most of the crust recycled into the mantle at subduction zones during the last $\sim 200$ My formed at fast spreading centers. Hence, an understanding of accretion processes at one deep drilling site might reasonably be extrapolated to describe a significant portion of the Earth's surface.

Drilling and sampling a complete crustal section will enable scientists to accurately estimate the bulk composition of the crust; understand the extent and intensity of hydrothermal exchange between the ocean crust and seawater; establish the chemical connections between the lavas that erupt at the seafloor and the melts that are separated from their mantle sources; more accurately estimate the chemical flux returned to the mantle by subduction; test competing models of lower crustal magmatic accretion; calibrate regional seismic measurements and the layered-crust models 


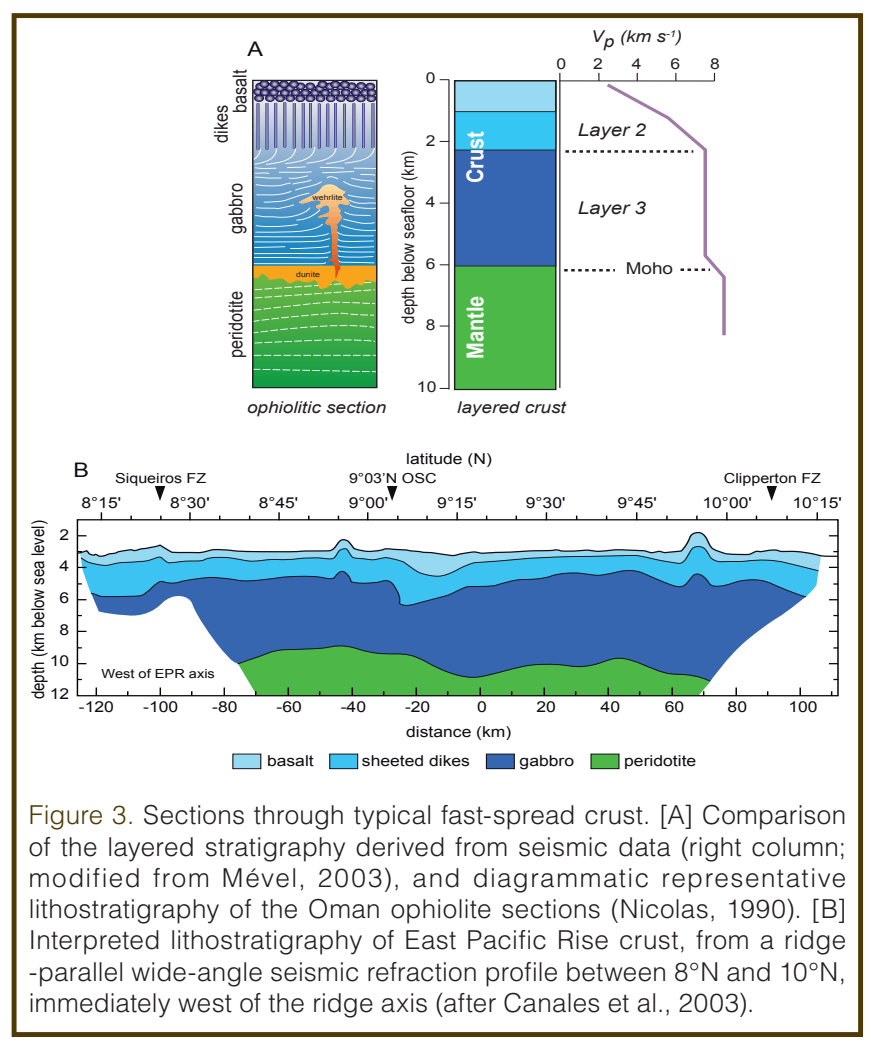

derived from them; better understand the origin of magnetic anomalies; and determine cooling rates of the lithosphere. Only by sampling across the crust-mantle boundary will we be able to define, at least in one place, the geological meaning of the Moho, determine the in situ composition of the uppermost mantle and its deformation, and address details of the physics and chemistry of mantle melt migration.

Essential complementary studies: The fundamental objective of fully penetrating the crust in at least one place must be supplemented by studies of spatial and temporal variability if a comprehensive understanding of the origin and evolution of the ocean lithosphere is to be achieved. In order to fully understand the architecture of the ocean crust, the slow-spread crust must be explored in different tectonic settings. For example, serpentinized mantle rocks are commonly incorporated into the crust (as defined seismically) at slow-spreading ridges. Drilling in this type of crust down to fresh peridotite will test competing hypotheses on the nature of the Moho. Is the Moho (1) the boundary between the residual upper mantle and the igneous crust, or (2) a broader zone of layered ultramafic and mafic rocks, or (3) a serpentinization front, or, perhaps, (4) some combination of these three? Slow-spread crust also offers windows of opportunity to relatively easily acquire long sections of lower crust (e.g., IODP Sites 735 and U1309).

The overarching goals of deep crustal drilling in slow-spread lithosphere are to efficiently characterize the spatial and temporal variability of crustal and upper mantle architecture, and to identify and constrain the key forcing functions that control this variability. To achieve these goals will require drilling to various depths at key sites that encompass much of the known vertical and lateral variability of slow-spread crust. Main objectives for this type of drilling, in addition to those listed above for the deep penetration of the crust, include:

- Determining the variability of the lithologic nature of the (seismic) Moho.

- Investigating the contrast between crust formed along volcanogenic parts of slow spreading ridges (segment centers) and lava-poor segment ends. Is crust from segment centers similar in structure to fast-spread crust?

- Understanding the relationships between crustal architecture and tectonic setting.

- Determining the depth to which seawater penetrates in different tectonic settings. Is there a relationship between crustal architecture and depth of seawater penetration?

- Investigating the chemical, mineralogical, and microbiological character and variability of hydrothermal systems.

Hydrothermal alteration of the oceanic crust encompasses a wide range of water-rock reactions that change the physical properties of the crust on a variety of temporal and spatial scales. One strategy for studying the aging of oceanic crust is to drill multi-hole transects along seafloor spreading flow lines to examine the time-integrated changes in physical and chemical properties. To date, drilling has been concentrated either relatively close to mid-ocean ridge axes or close to subduction zones; very few holes have been drilled in crust $\sim 20-80$ My old. There are, especially, no sites in $\sim 60-65$ My- old crust, which, based on heat flow measurements, is the average age at which the crust becomes sealed and the heat flux from the mantle becomes solely conductive. Further, seafloor alteration is spatially heterogeneous and variable in style. Although drilling cannot address this on a global scale, important information on styles and length scales of variability can be obtained by sampling and logging of closely spaced holes in conjunction with cross-hole experiments.

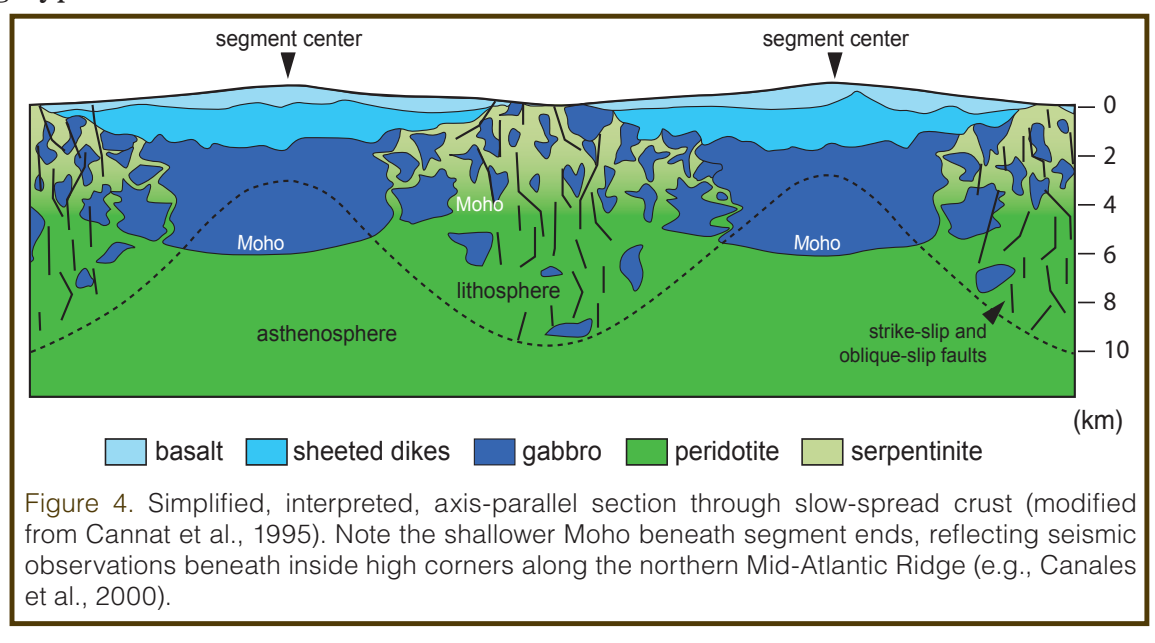




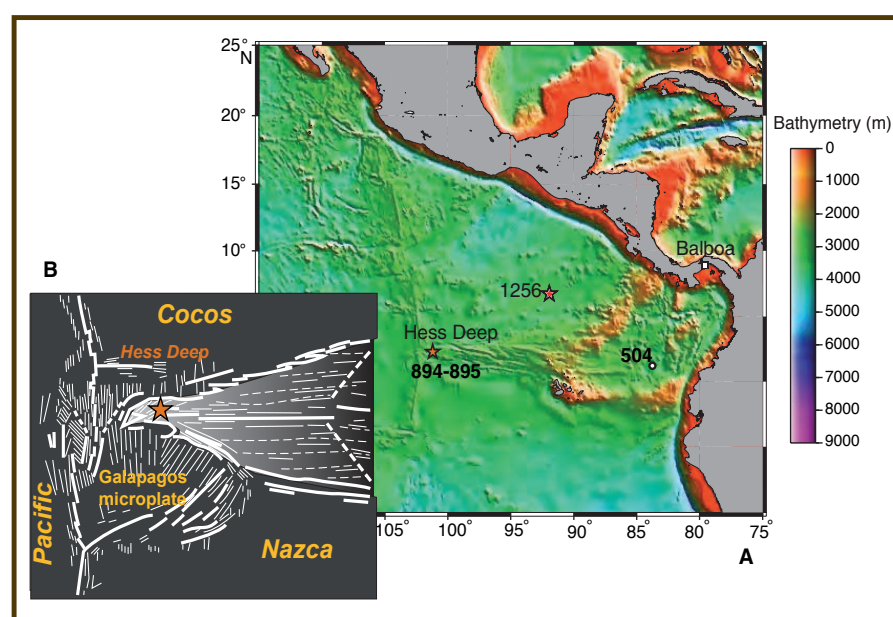

Figure 5. Recommended fast-spread crust sites. [A] Bathymetric map of the eastern Pacific, showing the locations of Site 1256 and Hess Deep (modified from Wilson et al., 2003). [B] Tectonic sketch map of the Pacific-Nazca-Cocos triple junction showing the location of Hess Deep.

The sub-seafloor biosphere also plays an important role in the chemical evolution of oceanic crust. The spatial distribution of microbes in the crust is not known but is likely influenced by host rock composition, temperature, and permeability. Progress in understanding sub-seafloor microbial distribution and its interactions with geochemical alteration processes will proceed hand-in-hand with determining the distribution of rock type, temperature, and permeability as a function of depth and crustal age, and learning how these relationships influence the distribution of microbial activity.

\section{Recommended Elements for Mission Moho}

Because of the inherent variability of oceanic lithosphere, a comprehensive program to achieve the scientific objectives outlined above, that is documenting and understanding the evolution of more than half of Earth's surface, is an enormous and complex task. Despite this complexity, and the diversity of individual scientific opinions and priorities, participants reached consensus on the core components of an operationally realistic Mission Moho. Mission Moho should focus on the ultimate goal of achieving full crustal penetration at a single fast-spread site. Progress towards this ultimate goal, both technological and scientific, will require drilling at various additional sites, including some in slow-spread crust.

Complete Crustal Penetration in Fast-Spread Crust: The workshop agreed by consensus that the primary goal of Mission Moho should be to achieve a deep penetration site in fast-spread crust. This would take advantage of the reduced crustal thickness, simpler crustal structure, and representative character of this tectonic setting. Designation of a primary site implies an ongoing commitment to work towards complete penetration through the gabbro of the lower crust into rocks that have mantle seismic velocities and into peridotitic residues of partial melting. Elements of the ongoing scientific drilling effort, which must be coordinated and combined with significant technical development and feasibility testing, will also support a number of science goals, both directly related, and ancillary, to the objective of full crustal penetration.

A few years ago, Site 1256 (Fig. 5A) was chosen to initiate a deep hole in fast-spread crust, starting with ODP Leg 206. This site was selected because it best met a majority of the criteria for a deep penetration site that were thoroughly discussed and listed by the ODP "Architecture of the Lithosphere" Program Planning Group (see the full workshop report, see also see Wilson et al., 2003 for full site justification). Site 1256 is located in the eastern equatorial Pacific, on 15-Ma-old crust of the Cocos plate that formed at a superfast spreading rate (Wilson, 1996). Based on a documented inverse relationship between spreading rate and depth to axial low velocity zones, inferred to be axial melt lenses (Purdy et al., 1992), Site 1256 was selected to provide the best possible chance of reaching gabbroic crust at the shallowest possible depth. After three expeditions (206, 309, and 312), Hole $1256 \mathrm{D}$ is currently rooted in a dikegabbro transition zone (Wilson et al., 2006; Fig. 2D). The gabbros so far have compositions similar to the overlying lavas and dikes. Cumulate rocks have not yet been encountered, and shipboard P-wave velocity measurements are characteristic of seismic layer 2 . The current temperature at the bottom of Hole $1256 \mathrm{D}$ is estimated as $\sim 115^{\circ} \mathrm{C}-125^{\circ} \mathrm{C}$. The Moho is imaged at the site at $5.5 \mathrm{~km}$ depth (Wilson et al., 2002).

To achieve full penetration of fast-spread crust, the following steps are recommended.

1. Site 1256 should be designated as the provisional primary site and deepened using current, riserless technology as far possible into gabbro to the point where further riserless drilling is technically not feasible. Further drilling will provide immediate and otherwise unavailable operational experience and fulfill a number of science goals, including confirming whether the hole has fully penetrated into crustal Layer 3.

2. Site identification and survey work should begin as soon as possible to identify and characterize one or more alternative complete crustal penetration site(s), in case conditions at Site 1256 prove to be unsatisfactory for full crustal penetration. The greatest currently perceived threat at Site 1256 is from potentially high down-hole temperatures. For this reason, the alternate site(s) should be on older crust. A critical limiting factor is that the site must be within reach of planned deep riser for the Chikyu. This limit is currently 4000 meters. If the design target for the riser could be increased to 4500 meters, the number of potential sites would be significantly higher (Fig. 6). Initial evaluations might encompass two or three sites, with a relatively rapid narrowing to a single site for the more intensive investigations. Activities at such sites might include: 
i) site survey activities including seafloor mapping, heat flow, and seismic studies to determine both sediment thickness and seismic structure,

ii) initial shallow drilling to determine the nature of the upper crust and its potential to maintain a stable hole during extended deep drilling operations, and

iii) deeper drilling, ideally at least to the dike-gabbro transition.

3. Additional drilling should be conducted at the primary site to establish spatial context including primary and secondary shallow crustal variability, permeability, and other characteristics.

4. Design work, including necessary technical and engineering development, should begin at the primary site for a deep, cased hole that is engineered for riser drilling through the full crust.

5. Enhanced site survey activities should be conducted at the primary site, including, but not necessarily limited to, high resolution deep seismic studies.

\section{Complementary drilling and context studies in fast-spread} crust: Boreholes are spatially limited, and they need to be understood in their broader context. Therefore, it is imperative that any site chosen for a deep penetration hole is thoroughly investigated and characterized. Conceptually, spatial context is also augmented by drilling in tectonic windows and by geological field studies of ophiolites, in particular the Oman ophiolite. Non-riser drilling in tectonic windows can potentially provide access to lower crust and uppermost mantle, the critical boundaries between crustal layers, and, possibly the crust-mantle boundary.

In fast-spread crust, the best known and most readily accessible tectonic window is the Hess Deep rift valley $\left(2^{\circ} \mathrm{N}\right.$, $101^{\circ}$ W; Fig. 5) near the Pacific-Cocos-Nazca triple junction. Hess Deep is the only place on the Earth's surface where a substantial section of fast-spread lower crust and shallow mantle is exposed at the seafloor and/or accessible via current nonriser drilling technology. Hess Deep is forming as the Cocos-Nazca ridge propagates westward into young ( 1 Ma) fast-spread lithosphere generated at the East Pacific Rise. Well-studied exposures of intact upper crust, from the upper gabbros to the lava sequence along the northern scarp, reveal significant lateralvariability in crustal structure and hydrothermal alteration (Francheteau et al., 1990; Karson et al., 1992, 2002). Deep crustal and shallow mantle sequences, dismembered by the Cocos-Nazca rifting, are also exposed, from an intra-rift ridge, southward to the axis of the Deep at $\sim 5400 \mathrm{~m}$ water depth.
Because of these unique exposures, Hess Deep provides a unique opportunity for shallow non-riser drilling to access lower crust and mantle sequences and transitions in fastspread oceanic crust (Gillis et al., 1993). Complementary studies in this 'natural laboratory' should be among the highest priorities for future investigations.

Complementary drilling in slow-spread crust: The second important goal of Mission Moho is to sample crust and upper mantle produced at low spreading rates (i.e., low magma flux), in order to at least partially address the variability of lithospheric architecture and of the nature of the Moho. Because slow-spread crustal architecture is highly variable, however, there is a broad range of scientific objectives and many drilling options available to address them. The extent to which current or planned drilling projects in slow-spread crust should be included in Mission Moho, and the criteria for inclusion of such projects, will have to be defined by a mission proponent team.

Nevertheless, some key objectives compatible with a Mission Moho emerged from the workshop. One key mission objective, requiring studies at numerous sites, is an assessment of the role of serpentinization in modifying the seismic signature of the ocean crust (e.g., Carlson and Miller, 1997; Mével, 2003) and the transition to typical mantle velocities. Seismic studies will, for the foreseeable future, continue to be the primary tool for investigation of the subsurface over wide areas. Understanding the relationship between lithologic variability and subsurface seismic images is a critical, ongoing goal that can only be reached by drilling multiple sections through non-layered, slow-spread crust.

Many sites (or types of sites) in various tectonic and magmatic settings were discussed as potentially relevant to Mission Moho scientific objectives, including three listed below.

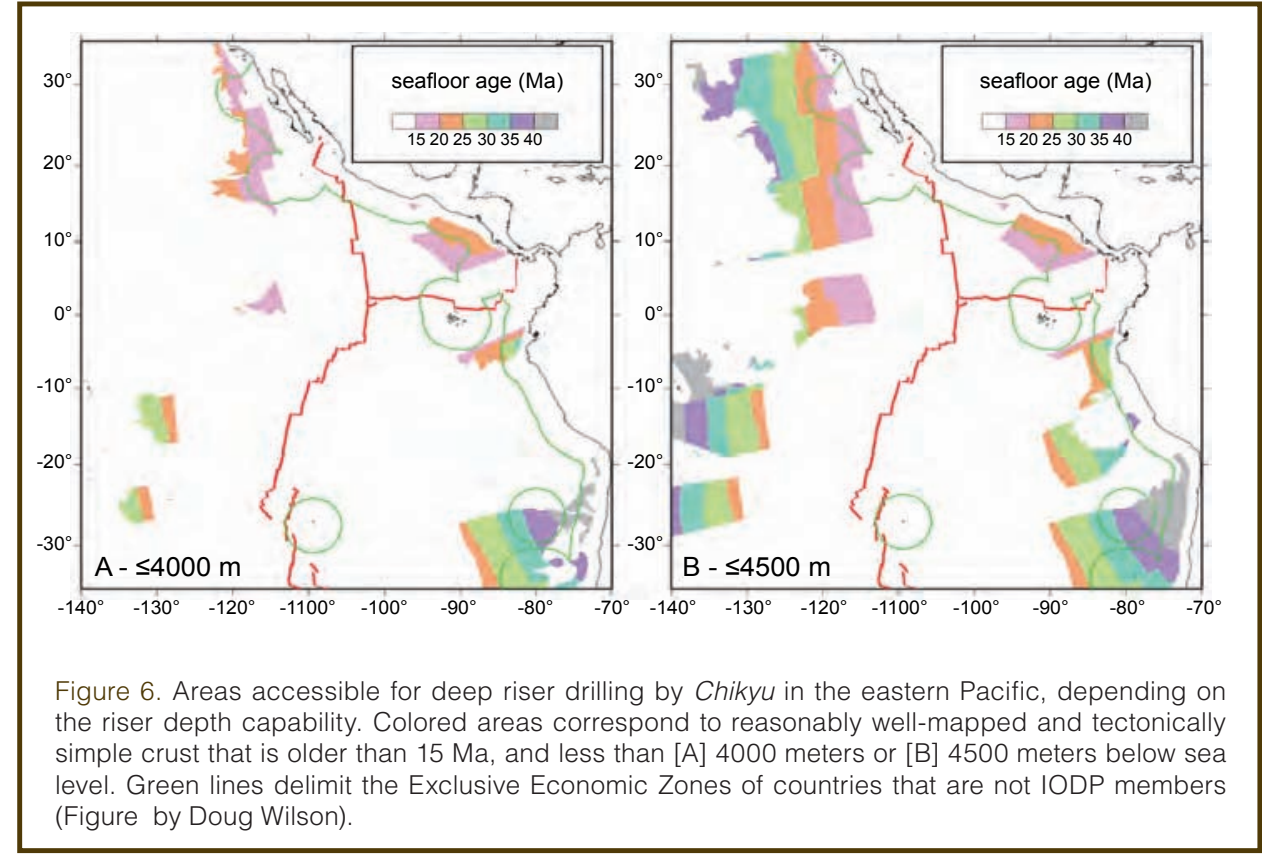


A) Sites in magma-rich, volcanogenic portions of slow-spread crust (e.g., DSDP Site 332, Mid-Atlantic Ridge, $37^{\circ} \mathrm{N}$ $34^{\circ} \mathrm{W}$; Lucky Strike segment, Mid-Atlantic Ridge, $37^{\circ} 20^{\prime} \mathrm{N}$ $\left.32^{\circ}-32^{\circ} 30^{\prime} \mathrm{W}\right)$ provide opportunities to compare and contrast magmatically robust parts of slow-spreading centers with fast-spreading ridges. ODP Site $332, \sim 1800 \mathrm{~m}$ below sea level, was drilled during DSDP Leg 37 and penetrated $310 \mathrm{~m}$ into basement. Drilling conditions and water depth at this site are suitable for relatively deep, non-riser drilling into the upper, basaltic crust. The Lucky Strike segment of the Mid-Atlantic ridge is well known, although it has not been surveyed specifically for drilling (e.g., Escartin et al., 2001; Singh et al., 2006). Lucky Strike is one of the main sites of the long-term monitoring of the Mid-Atlantic ridge (MoMAR) initiative, offering a potential opportunity to link a deep borehole with local seafloor observatories.

B) Sites in oceanic core complexes offer a large number of drilling options, including the opportunity to penetrate tectonically uplifted Moho. The two deepest holes in slowspread ocean crust-and two of the four deepest holes in ocean crust-are ODP Hole 735B (1508 m deep; Dick et al., 1999, Fig. 2A) in Atlantis Bank (Southwest Indian Ridge, $33^{\circ} \mathrm{S} 57^{\circ} \mathrm{E}$ ), and IODP Hole U1309D (1415 m deep; Blackman et al., 2006; Fig.2B) in Atlantis Massif (MidAtlantic Ridge, $30^{\circ} \mathrm{N} 42^{\circ} \mathrm{W}$ ).

- IODP Hole U1309D is open and in good condition, offering the opportunity to drill deeper at any time. Its apparent seafloor age is young $(\sim 2 \mathrm{Ma})$, likely too warm to allow drilling beyond $2-3 \mathrm{~km}$. Nevertheless, continuing this hole as far as possible with current, nonriser technology will provide valuable operational experience, test drilling feasibility in relatively young gabbroic crust, and most certainly provide unique additional scientific return on lower crustal processes at slow-spread ridges. The operational experience is independent of spreading rate and will be directly relevant to fast-spread crust.

- ODP Hole 735B is located in older ( $11 \mathrm{Ma})$ crust, and could be a suitable place for deep drilling, and eventually testing the proposed models of slow-spread crustal architecture (Dick et al., 2007).

- Three other potential sites that have site survey data available include Kane megamullion, Mid-Atlantic Ridge, $23^{\circ} 30^{\prime} \mathrm{N} 45^{\circ} 30^{\prime} \mathrm{W}$; Godzilla megamullion, Parecevela Basin, $16^{\circ} \mathrm{N} 139^{\circ} \mathrm{E}$; and Uraniwa-Hills, Central Indian Ridge, $25^{\circ} \mathrm{S} 70^{\circ} \mathrm{E}$.

C) A site in ultra-slow-spread crust (e.g., eastern Southwest Indian Ridge, $26-31^{\circ} \mathrm{S} 61-66^{\circ} \mathrm{E}$; Gakkel Ridge; Arctic Ocean) could address objectives related to global-scale spatial variability of the crust. In addition, the abundance of mantle peridotites exposed along ultra-slow spreading centers suggests that a well-chosen site might achieve a long-standing elusive goal-to access fresh peridotite by relatively shallow drilling. In the Indian Ocean, "smooth" sea-floor areas interpreted as being the expression of the lowest magmatic activity (Cannat et al., 2006) are generally less than $4000 \mathrm{~m}$ deep and therefore accessible to future riser drilling by the Chikyu. The Gakkel ridge in the Arctic (e.g., Michael et al., 2003) offers similar settings, but its extreme northern latitude would require special (MSP) drilling arrangements.

\section{Mission Moho: a Technological Challenge}

Penetrating the entire ocean crust will require riser drilling technology. The world's only scientific riser drilling vessel Chikyu ("Earth" in Japanese) is scheduled to start operations for IODP in September 2007. For eventual penetration of fast-spread oceanic crust, a technically challenging modification of the riser will be required, from the current 2500-m maximum water depth to at least $4000 \mathrm{~m}$ (preferably $4500 \mathrm{~m}$ ). The construction of such a deep-water riser was recently included as one of five domestic science and technology high priorities by the Japanese government.

Technological requirements for Mission Moho scientific objectives were discussed at the Mission Moho workshop by a special panel that included several drilling engineers. In addition to deep drilling, the panel considered improved core recovery, the ability to obtain oriented cores, and higher temperature tolerances $\left(>150^{\circ} \mathrm{C}-200^{\circ} \mathrm{C}\right)$ for drilling, and especially logging tools. More experience is needed to drill in high temperature conditions, especially to understand the effects of thermal stress on hole stability in ocean crust lithologies. The temperature and cost limits beyond which we are unlikely to successfully drill are currently unknown. They will need to be established through the experience of drilling progressively deeper holes.

In planning for Mission Moho, the following broad guidelines should be considered:

- To achieve a Mission Moho requires a commitment to a 10-year program of increasing complexity.

- Mission Moho will occupy about 4-6 sites, including at least one primary and one alternate site as well as several complementary sites. Most sites will require multiple expeditions-we estimate 12 to 20 expeditions in total.

- A riser capable of drilling in at least $4000 \mathrm{~m}$ water depth will be required for the second half of the 10-year mission.

If the riser can be engineered for $4500 \mathrm{~m}$ water depth, the range of possible sites is significantly increased (Fig. 6). Whether this is achievable must be known early in the mission to allow for final selection of a deep penetration site.

The journey to Moho will be long, but the challenges to our imagination and the potential for major scientific discoveries along the road are enormous. Each of the diverse recommended activities is essential to build a scientific and 
operational knowledge base that will ultimately enhance our ability to design and execute an ultra-deep drill hole that will penetrate all the way to the Earth's mantle.

\section{Acknowledgements}

The Mission Moho workshop was held in Portland Oregon on 7-9 September 2006. It was funded by the IODP, the Joint Oceanographic Institutions (JOI), the Ridge 2000 program, and the InterRidge initiative. This report builds on many fruitful and passionate discussions during the workshop, and we express our deepest thanks to all workshop participants. Several of them contributed to the writing of the full workshop report.

\section{References}

Alt, J.C., Miyashita, S., Teagle, D.A.H., Umino, S., Banerjee, N., and the Expeditions 309/312 Scientists, in press. Proc. IODP, 309/312: College Station, Texas (Integrated Ocean Drilling Program Management International, Inc.).

Bascom, W.N., 1961. A Hole in the Bottom of the Sea; The Story of the Mohole Project: New York (Doubleday and Company, Inc) $352 \mathrm{p}$.

Becker, K., Sakai, H., Merrill, R.B., Adamson, A.C., Alexandrovich, J., Alt, J.C., Anderson, R.N., Bideau, D., Gable, R., Herzia, P. M., Houghton, S., Ishizuka, H., Kawahata, H., Kinoshita, H., Lovell, M.A., Malpas, J., Masuda, H., Morin, R.H., Motti, M. J., Pariso, J.E., Pezard, P., Phillips, J., Sparks, J., and Uhlig, S., 1988. Proc. ODP, Init. Rept., 111: College Station, Texas (Ocean Drilling Program). doi:10.2973/odp.proc. ir.111.1988

Blackman, D.K., Ildefonse, B., John, B.E., Ohara, Y., Miller, D.J., MacLeod, C.J., and the Expedition 304/305 Scientists, 2006. Proc. IODP, 304/305: College Station, Texas (Integrated Ocean Drilling Program Management International, Inc.). doi:10.2204/iodp.proc.304305.2006

Canales, J.P., Detrick, R.S., Lin, J., Collins, J.A., and Toomey, D.R., 2000. Crustal and upper mantle seismic structure beneath the rift mountains and across a nontransform offset at the Mid-Atlantic Ridge (35 N). J. Geophys. Res., 105:2699-2719. doi:10.1029/1999JB900379

Canales, J.P., Detrick, R.S., Toomey, D.R., and Wilcock, W.S.D., 2003. Segment-scale variations in the crustal structure of 150-300 kyr old fast spreading oceanic crust (East Pacific Rise, $8^{\circ} 15^{\prime}$ $\left.\mathrm{N}-10^{\circ} 5^{\prime} \mathrm{N}\right)$ from wide-angle seismic refraction profiles. Geophys. J. Int., 152:766-794. doi:10.1046/j.1365246X.2003.01885.x

Cannat, M., 1993. Emplacement of mantle-rocks in the seafloor at mid-ocean ridges. J. Geophys. Res., 98:4163-4172.

Cannat, M., Mevel, C., Maia, M., Deplus, C., Durand, C., Gente, P., Agrinier, P., Belarouchi, A., Dubuisson, G., Humler, E., and Reynolds, J., 1995. Thin crust, ultramafic exposures, and rugged faulting patterns at Mid-Atlantic Ridge (22 degrees 24 degrees N). Geology, 23:49-52. doi:10.1130/00917613(1995)023<0049:TCUEAR>2.3.CO;2

Cannat, M., Sauter, D., Mendel, V., Ruellan, E., Okino, K., Escartin, J., Combier, V., and Baala, M., 2006. Modes of seafloor generation at a melt-poor ultraslow-spreading ridge. Geology,
34:605-608. doi:10.1130/G22486A.1.doi:10.1130/G22486.1

Carlson, R.L., and Miller, D.J., 1997. A new assessment of the abundance of serpentinite in the oceanic crust. Geophys. Res. Lett., 24(4):457-460. doi:10.1029/97GL00144

Detrick, R.S., Harding, A.J., Kent, G.M., Orcutt, J.A., Mutter, J.C., and Buhl, P., 1993. Seismic structure of the southern East Pacific Rise. Science, 259:499-503. doi:10.1126/science. 259.5094.499

Dick, H.J.B., 1989. Abyssal peridotites, very slow spreading ridges and ocean ridge magmatism. In Saunders, A.D., and Norry, M.J. (Eds.), Magmatism in the Ocean Basins, Geol. Soc. Spec. Pub. 42:71-105.

Dick, H.J.B., Natland, J.H., and Ildefonse, B., 2006. Past and future impact of deep drilling in the ocean crust and mantle: an evolving order out of new complexity. Oceanography, 19:4. $72-80$.

Dick, H.J.B., Natland, J.H., Miller, D.J., Alt, J.C., Bach, W., Bideau, D., Gee, J.S., Haggas, S., Hertogen, J.G.H., Hirth, G., Holm, P.M., Ildefonse, B., Iturrino, G.J., John, B.E., Kelley, D.S., Kikawa, E., Kingdon, A., Le Reoux, P.J., Maeda, J., Meyer, P.S., Naslund, H.R., Niu, Y., Robinson, P.T., Snow, J.E., Stephen, R.A., Trimby, P.W., Worm, H-U, and Yoshinobu, A., 1999. Proc. ODP, Init. Repts., 176 [Online]. Available from World Wide Web: http://www-odp.tamu.edu/publications/176_IR/176TOC.HTM.

Escartin, J., Cannat, M., Pouliquen, G., Rabain, A., and Lin, J., 2001. Constraints on the interaction between the Mid-Atlantic Ridge and the Azores hotspot from bathymetry and gravity (36-39N). J. Geophys. Res., 106:21719-21736.

Expedition 309 and 312 Scientists, 2006. Superfast spreading rate crust 3: a complete in situ section of upper oceanic crust formed at a superfast spreading rate. IODP Prel. Rept., 312. doi:10:2204/iodp.pr.312.2006.

Francheteau, J., Armijo, R., Cheminée, J.L., Hekinian, R., Lonsdale, P., and Blum, N., 1990. 1 My East Pacific Rise oceanic crust and uppermost mantle exposed by rifting in Hess Deep (equatorial Pacific Ocean). Tectonophysics, 151:1-26.

Gillis, K., Mével, C., Allan, J., Arai, S., Boudier, F., Célérier, B., Dick, H.J.B., Falloon, T.J., Früh-Green, G., Iturrino, G.J., Kelley, D.S., Kelso, P., Kennedy, L.A., Kikawa, E., Lecuyer, C.M., MacLeod, C.J., Malpas, J., Manning, C.E., McDonald, M.A., Miller, D.J., Natland, J., Pariso, J.E., Pedersen, R-B, Prichard, H.M., Puchelt, H., and Richter, C., 1993. Proc. ODP, Init. Repts., 147: College Station, Texas (Ocean Drilling Program).

Hooft, E., Schouten, H., and Detrick, R.S., 1996. Constraining crustal emplacement processes from the variation in seismic layer 2A thickness at the East Pacific Rise. Earth Planet. Sci. Lett., 142:289-309. doi:10.1016/0012-821X(96)00101-X

Ildefonse, B., Blackman, D.K., John, B.E., Ohara, Y., Miller, D.J., MacLeod, C.J., and the IODP Expeditions 304/305 Scientists, 2006. IODP Expeditions $304 \& 305$ characterize the lithology, structure, and alteration of an oceanic core complex. Scientific Drilling, 3:4-11. doi:10.2204/iodp. sd.3.01.2006.

Ildefonse, B., Rona, P.A., and Blackman, D.K., 2007. Deep sampling of the crust formed at mid-ocean ridges: scientific ocean drilling provides perspective 'in-depth'. Oceanogr., 20 (1): 22-33. Special Issue on InterRidge. 
International Working Group, 2001. Earth, oceans and life: scientific investigation of the Earth system using multiple drilling platforms and new technologies. Integrated Ocean Drilling Program Initial Science Plan, 2003-2013: Washington, DC (International Working Group Support Office).

Karson, J.A., and Elthon, D., 1987. Evidence for variations in magma production along oceanic spreading centers - a critical appraisal. Geology, 15:127-131. doi:10.1130/00917613(1987)15<127:EFVIMP>2.0.CO;2

Karson, J.A., Hurst, S.D., and Lonsdale, P., 1992. Tectonic rotations of dikes in fast-spread oceanic crust exposed near Hess Deep. Geology,20:685-688.doi:10.1130/0091-7613(1992)020<0685: TRODIF $>2.3 . \mathrm{CO} ; 2$

Karson, J.A., Klein, E.M., Hurst, S.D., Lee, C.E., Rivizzigno, P.A., Curewitz, D., Morris, A.R., and Hess Deep '99 Scientific Party, 2002. Structure of uppermost fast-spread oceanic crust exposed at the Hess Deep Rift: implications for subaxial processes at the East Pacific Rise. Geochem. Geophys. Geosyst., 3 (1), 1002. doi:10.1029/2001GC000155.

Kelemen, P.B., Kikawa, E., Miller, D.J., Abe, N., Bach, W., Carlson, R.L., Casey, J.F., Chambers, L.M., Cheadle, M., Cipriani, A., Dick, H.J.B., Faul, U., Garces, Mi., Garrido, C., Gee, J.S., Godard, M.M., Graham, D.W., Griffin, D.W., Harvey, J., Ildefonse, B., Iturrino, G.J., Josef, J., Meurer, W.P., Paulick, H., Rosner, M., Schroeder, T., Seyler, M., and Takazawa, E., 2004. Proc. ODP, Init. Repts., 209: College Station, Texas (Ocean Drilling Program). doi:10.2973/odp.proc. ir.209.2004.

Macdonald, K., Sempere, J.C., and Fox, P.J., 1984. East Pacific Rise from Siqueiros to Orozco fracture zones: along-strike continuity of axial neovolcanic zone and structure and evolution of overlapping spreading centers. J. Geophys. Res., 89:60496069.

Mével, C., 2003. Serpentinization of abyssal peridotites at mid-ocean ridges. C. R. Geoscience, 335:825-852. doi:10.1016/j. crte.2003.08.006

Michael, P.J., Langmuir, C.H., Dick, H.J.B., Snow, J.E., Goldstein, S.L., Graham, D.W., Lehnert, K., Kurras, G., Jokat, W., Muhe, R., and Edmonds, H.N., 2003. Magmatic and amagmatic seafloor generation at the ultraslow-spreading Gakkel ridge, Arctic Ocean. Nature, 423:956-961. doi:10.1038/nature01704

Nicolas, A., 1990. Les montagnes sous la mer. Orleans, France (Editions du BRGM), 187 p.

Penrose Conference Participants, 1972. Penrose field conference on ophiolites. Geotimes, 17:24-25.

Purdy, G.M., Kong, L.S.L., Christeson, G.L., and Solomon, S.C., 1992. Relationship between spreading rate and the seismic structure of mid-ocean ridges. Nature, 355:815-872. doi: $10.1038 / 355815 \mathrm{a} 0$

Shor, E.N., 1985. A chronology from Mohole to JOIDES. In Drake, E.T., and Jordan, W.M. (Eds.), Geologists and Ideas; A History of North American Geology. Geol. Soc. Am. Spec. Publ. 4:391 -399 .

Singh, S.C., Crawford, W.C., Carton, H., Seher, T., Combier, V., Cannat, M., Canales, J.P., Dusunur, D., Escartin, J., and Miranda, J.M., 2006. Discovery of a magma chamber and faults beneath a Mid-Atlantic Ridge hydrothermal field. Nature, 442:1029-1032. doi:10.1038/nature05105
Wilson, D.S., 1996. Fastest known spreading on the Miocene CocosPacific plate boundary. Geophys. Res. Lett., 23:3003-3006. doi:10.1029/96GL02893

Wilson, D.S., Teagle, D.A.H., Acton, G.D., and Firth, J.V., 2002. Leg 206 Scientific Prospectus: An in situ section of upper oceanic crust created by superfast seafloor spreading. Scientific Prospectus \#206: College Station, Texas (Ocean Drilling Program), http://www-odp.tamu.edu/publications/ prosp/206_prs/206toc.html.

Wilson, D.S., Teagle, D.A.H., Alt, J.C., Banerjee, N.R., Umino, S., Miyashita, S., Acton, G.D., Anma, R., Barr, S.R., Belghoul, A., Carlut, J., Christie, D.M., Coggon, R.M., Cooper, K.M., Cordier, C., Crispini, L., Durand, S.R., Einaudi, F., Galli, L., Gao, Y.J., Geldmacher, J., Gilbert, L.A., Hayman, N.W., Herrero-Bervera, E., Hirano, N., Holter, S., Ingle, S., Jiang, S.J., Kalberkamp, U., Kerneklian, M., Koepke, J., Laverne, C., Vasquez, H.L.L., Maclennan, J., Morgan, S., Neo, N., Nichols, H.J., Park, S.H., Reichow, M.K., Sakuyama, T., Sano, T., Sandwell, R., Scheibner, B., Smith-Duque, C.E., Swift, S.A., Tartarotti, P., Tikku, A.A., Tominaga, M., Veloso, E.A., Yamasaki, T., Yamazaki, S., and Ziegler, C., 2006. Drilling to gabbro in intact ocean crust. Science 312:1016-1020. doi:10.1126/science. 1126090

Wilson, D.S., Teagle, D.A.H., Acton, G.D., Alt, J.C., Banerjee, N.R., Barr, S.R., Coggon, R., Cooper, K.M., Crispini, L., Einaudi, F., Jiang, S., Kalberkamp, U., Laverne, C., Nichols, H.J., Sandwell, R., Tartarotti, P., Umino, S., and Xiegler, C., 2003. Proc. ODP, Init. Repts., 206: College Station, Texas (Ocean Drilling Program). doi:10.2973/odp.proc.ir.206.2003.

\section{Authors}

Benoit Ildefonse, CNRS, Université Montpellier 2, Montpellier cedex05 34095, France, e-mail: benoit.ildefonse@univ-montp2.fr

David M. Christie, School of Fisheries and Ocean Sciences, University of Alaska Fairbanks, 213 O’Neill, P.O. Box 757220 , Fairbanks, Alaska 99775-7220, U.S.A.

and Mission Moho Workshop Steering Committee (Natsue Abe, Shoji Arai, Wolfgang Bach, Donna Blackman, Robert Duncan, Emilie Hooft, Susan Humphris, and Jay Miller)

\section{Related Web Links}

Full workshop report:

http://www.iodp.org/ocean-lithosphere/\#7

Momar: http://www.ipgp.jussieu.fr/rech/lgm/MOMAR/

Chikyu: www.jamstec.go.jp/chikyu/eng

IODP: www.iodp.org

Joint Oceanographic Institutions: www.joiscience.org

Ridge 2000 program: www.ridge2000.org

InterRidge initiative: www.interridge.org 